\title{
Does spirometric tests meet the acceptability criteria? Data from a tertiary chest hospital in Turkey
}

\author{
Kurtuluş $\mathrm{AKSU}^{1}$ (ID) \\ Ali \\ FIRINCIOĞLULARI ${ }^{1}$ (ID) \\ Funda $\operatorname{AKSU}^{1}(\mathrm{ID})$
}

\author{
${ }^{1}$ Department of Chest Diseases, Health Sciences University, Atatürk Chest \\ Diseases and Chest Surgery Training and Research Hospital, Ankara, Turkey \\ ${ }^{1}$ Sağlık Bilimleri Üniversitesi, Ankara Atatürk Gögüs Hastalıkları ve \\ Gögüs Cerrahisi Eğitim ve Araştırma Hastanesi, Gögüus Hastalıkları Kliniği, \\ Ankara, Türkiye
}

Cite this article as: Aksu K, Fırıncıoğluları A, Aksu F. Does spirometric tests meet the acceptability criteria? Data from a tertiary chest hospital in Turkey. Tuberk Toraks 2020;68(2):112-117.

Yazışma Adresi (Address for Correspondence)

Dr. Kurtuluş AKSU

Ankara Atatürk Sanatoryumu Hastanesi,

Keçiören 06290, ANKARA - TÜRKIYE

e-mail: kurtulusaksu@yahoo.com

CCopyright 2020 by Tuberculosis and Thorax.

Available on-line at www.tuberktoraks.org.com

\begin{abstract}
Does spirometric tests meet the acceptability criteria? Data from a tertiary chest hospital in Turkey

Introduction: First step is to evaluate the quality of the test in interpreting spirometries. International societies have defined the acceptability criteria for spirometric tests. With this study, it was aimed to evaluate spirometric tests in terms of compliance with international acceptability criteria and to determine error types.
\end{abstract}

Materials and Methods: Spirometric manoeuvres held at a tertiary chest diseases hospital were evaluated as to whether the acceptability criteria of "American Thoracic Society/European Respiratory Society (ATS/ERS)" guideline were maintained or not. Errors determined were classified as unexplosive start of expiration, submaximal effort, cough, closure of glottis, missing closure of the loop ring and early termination of expiration.

Results: Among tests evaluated ( $n=510), 276$ (54.1\%) belonged to female and $234(45.9 \%)$ to male subjects. Average age of subjects was $56.1 \pm 15.0$ years. It was noted that $318(62.4 \%)$ of the tests met acceptability criteria, whereas $192(37.6 \%)$ did not. The most frequently noted error type is submaximal effort by $30.2 \%$ followed by missing closure of the loop, early terminaton of expiration, coughing, unexplosive start of expiration and closure of glottis. In the tests whose spirometric maneuvers did not meet the criteria, the mean age of the patients was significantly higher than in the appropriate tests. When the cases were grouped according to their age, it was observed that the rate of conformity of spirometric examinations decreased significantly as the age range increased.

Conclusion: Within this study it is the first time in our country that evaluation of spirometric studies has been made to see the rate of conformity with international standarts. Although it is thought that spirometric examinations are not technically appropriate in clinical practice throughout our country, there is no data in the literature. Although the center where the study is conducted is a 
tertiary chest diseases hospital, the data obtained reveal that in spirometric evaluations, a substantially non-standard examination was performed.

Key words: Spirometry; international guidelines; acceptability criteria

ÖZ

Spirometrik incelemeler kabul edilebilirlik kriterlerini sağlıyor mu? Türkiye'de üçüncü basamak göğüs hastalıkları hastanesi verisi

Giriş: Spirometri sonuçlarının değerlendirilmesinde ilk basamak, testin kalitesinin değerlendirilmesidir. Uluslararası cemiyetler spirometrik incelemelerin değerlendirmeye alınabilmesi için manevralarda sağlanması gereken kabul edilebilirlik kriterlerini belirlemişlerdir. Bu çalışma ile spirometrik testlerin uluslararası kabul edilebilirlik kriterlerine uygunluk açısından değerlendirilmesi ve hata tiplerinin belirlenmesi amaçlanmıştır.

Materyal ve Metod: Üçüncü basamak göğüs hastalıkları hastanesinde yapılan spirometrik manevralar, "American Thoracic Society/ European Respiratory Society (ATS/ERS)" rehberinin kabul edilebilirlik kriterlerini sağlayıp sağlamadı̆̆ı yönünde değerlendirildi. Testlerde saptanan hatalar ekspirasyona yavaş başlama, yetersiz efor, öksürük, glottisin erken kapanması, ekspirasyon halkasının kapanmaması ve yetersiz ekspirasyon süresi şeklinde sınıflandırıldı.

Bulgular: Değerlendirmeye alınan testlerin ( $n=510) 276$ (\%54.1)'sı kadın, 234 (\%45.9)'ü erkek olgulara aitti. Olguların yaş ortalaması $56.1 \pm 15.0$ yıldı. Testlerin 318 (\%62.4)'inin spirometrik manevranın uygunluk kriterlerini sağladığı, 192 (\%37.6)'sinin sağlamadığı izlenmişsir. En sık tespit edilen hata tipi \%30.2 ile yetersiz efor olmuştur. Bunu sırasıyla ekspirasyon halkasının kapanmaması, yetersiz ekspirasyon süresi, öksürük, ekspirasyona yavaş başlama ve glottisin erken kapanması izlemiştir. Spirometrik manevraları kriterlere uygun olmayan olgularda yaş ortalaması, uygun olan olgulara göre istatistiksel olarak anlamlı oranda yüksek bulunmuştur. Olgular yaşlarına göre gruplandırıldı̆̆ında yaş aralığı arttıkça spirometrik incelemelerin uygunluk oranının anlamlı olarak düştüğü görülmüştür.

Sonuç: Bu çalışma ile ülkemizde ilk olarak spirometrik incelemelerin uluslararası kılavuzlara uygunluk oranı değerlendirilmiştir. Ülkemiz genelinde klinik pratikte spirometrik incelemelerin teknik olarak yeterince uygun yapılmadığının bir sorun olduğu düşünülmekle birlikte literatürde bu konuda veri bulunmamaktadır. Spirometrinin en sık kullanıldığı branş göğ̈̈s hastalıkları olup testin tekniğine uygun yapılması da en sık bu branşın klinik pratiğini etkilemektedir. Çalışmanın yürütüldüğ̈̈ merkez üçüncü basamak göğüs hastalıkları hastanesi olmasına karşın elde edilen veriler spirometrik değerlendirmelerde önemli oranda standartlara uygun olmayan inceleme yapıldığını ortaya koymaktadır.

Anahtar kelimeler: Spirometri; kılavuz; kabul edilebilirlik kriterleri

\section{INTRODUCTION}

Spirometry is one of the basic diagnostic tools used in measuring lung functions. Performing a proper spirometric test is essential for identification and management of respiratory diseases (1).

The most basic requirement when performing spirometry is appropriate technique to assure quality of the test. Spirometry quality assurance involves examining test values for proof of technical values and evaluating both volume-time and flow-volume curves. Technically improper spirometry may have little value and may even provide misleading information (2). International communities have established standards and requirements for performing spirometric tests (3). These international criteria has also been stated in national guidelines on spirometry and laboratory standards (4).

Spirometric manoeuvres consist of three phases which are; maximal inspiration, blast of exhalation and continued complete exhalation to the end of test (3).
Spirometric manoeuvres should meet start of test and end of test criteria according to guidelines. The extrapolated volume must be less than $5 \%$ of the forced vital capacity or less than $150 \mathrm{~mL}$ in order to assure forced expiratory volume in 1 second comes from a maximal effort curve. For this reason if the technician detects a hesitant start in expiration she should terminate and restart the spirometric test. Accordingly, inspection of the flow-volume curve by the clinician is essential to measure the satisfactory start of spirometric test. Achievement of maximal effort is also important for evaluation of peak expiratory flow rates. A sharp rise and occurence of peak expiratory flow close to the point of start of exhalation should be guaranteed (3).

End of test criteria should also be met for manoeuvre acceptability. To achieve this, during spirometric tests, subjects should obtain optimal effort. Technicians should encourage subjects to continue exhalation to the end of the manoeuvre by telling them to keep going. Otherwise a spirometric test which does not 
meet end of test criteria will result mainly in misinterpreteration of forced vital capacity. Two different criteria are optional for a spirometric test meet end of test criteria. First of them is that, expiration must be continued until subjects cannot or should not continue further exhalation. Optionally, the second criteria is that the subject has tried to exhale for $\geq 6$ seconds and volume-time curve shows no change in volume for $\geq 1$ second (plateau criteria) (3).

Moreover, even if duration of exhalation exceeds 6 seconds, if a closure of the glottis occurs then the manoeuvre may prematurely terminate at less than 6 seconds. Accordingly, technicians should be aware of end of test criteria and abscence of glottis closure to ensure a correct procedure. Additionally coughing render a test unacceptable and it interferes with the measurement of accurate results (3).

For the clinicians, the first step in the evaluation of spirometric results must be reassurance of the quality of the test. Acceptability criteria are, as indicated above, are essential for correct measurements of lung functions and evaluation of spirometric tests which do not conform the international criteria may be misinterpreted. Evaluation of flow-volume curves should be the first step in interpreting spirometric tests. An unexplosive start of expiration, submaximal effort, cough, closure of glottis, missing closure of the loop ring and early termination of expiration detected in flow-volume curve indicates that the test fails to conform acceptability criteria.

There is no data on the rate of compliance of spirometric evaluations in our country. The aim of the present study is to evaluate the conformity of internationally accepted criteria to spirometric tests and to determine the type of errors.

\section{MATERIALS and METHODS}

The study was approved by local hospital committee (30.05.2019/630).

\section{Study Design and Conformity Assessment of Spirometric Tests}

Spirometric tests held in a tertiary chest diseases hospital spirometry laboratory with different spirometers by different technicians were assessed in means of international acceptability criteria (3). The spirometric test results taken into consideration were randomly selected from all examinations performed in JanuaryDecember 2017.
Spirometric tests were examined on the basis of spirometric manoeuvre being appropriate to guidelines or containing one of the errorrs identified in the guidelines. Accordingly, the errors were classified as unexplosive start of expiration, submaximal effort, coughing in the first second, closure of glottis, missing closure of the loop ring and early termination of expiration. Spirometric tests were evaluated as 'non-conforming' if they contain any of the specified errors, and 'conforming' if they do not contain any of the errors. The proportion of spirometric tests that meet and do not meet international acceptability criteria is noted. Error types were determined in nonconforming spirometric tests. The proportion of conforming and non-conforming spirometric tests was evaluated according to the age and gender of the patients.

\section{Statistical Analysis}

Continuous variables were expressed as mean \pm standard deviation whereas categorical variables were expressed as numbers and percentages. For comparison of continuous variables Student's t-test and for comparison of caterogical variables Chi-square test was used. All statistical tests were two-sided and a $\mathrm{p}$ value $<0.05$ was considered statistically significant. The analyses were performed using SPSS (Statistical Package for the Social Sciences) ${ }^{\circledR}$ version 22.

\section{RESULTS}

Five-hundred and ten spirometric tests were evaluated in means of conforming the international acceptability criteria. Of these tests 276 (54.1\%) belonged to female and 234 (45.9\%) to male subjects. Average age of subjects was $56.1 \pm 15.0$ years. It was noted that $318(62.4 \%)$ of the tests provided acceptability criteria, $192(37.6 \%)$ did not. The most frequently noted error type is submaximal effort by $30.2 \%$ followed by missing closure of the loop, early terminaton of expiration, coughing, unexplosive start of expiration and closure of glottis (Table 1).

Table 1. Frequencies of error types in spirometric tests ( $n=192$ )

\begin{tabular}{lc} 
Submaximal effort & $58(30.2 \%)$ \\
Missing closure of the loop & $42(21.9 \%)$ \\
Early terminaton of expiration & $42(21.9 \%)$ \\
Coughing & $29(15.1 \%)$ \\
Unexplosive start of expiration & $19(9.9 \%)$ \\
Closure of glottis & $2(1.0 \%)$ \\
\hline
\end{tabular}

Data are expressed as n (\%). 
Table 2. Distribution of age and gender in cases of conforming and non-conforming spirometric manoeuvres

\begin{tabular}{|c|c|c|c|}
\hline & $\begin{array}{c}\text { Spirometric manoeuvres } \\
\text { conforming cases }(n=318)\end{array}$ & $\begin{array}{l}\text { Spirometric manoeuvres non- } \\
\text { conforming cases }(n=192)\end{array}$ & $\mathbf{p}$ \\
\hline Age (year) & $53.0 \pm 14.6$ & $61.3 \pm 14.3$ & $<0.001$ \\
\hline Gender & & & 0.361 \\
\hline Female & $167(52.5 \%)$ & 109 (56.8\%) & \\
\hline Male & $151(47.5 \%)$ & $83(43.2 \%)$ & \\
\hline
\end{tabular}

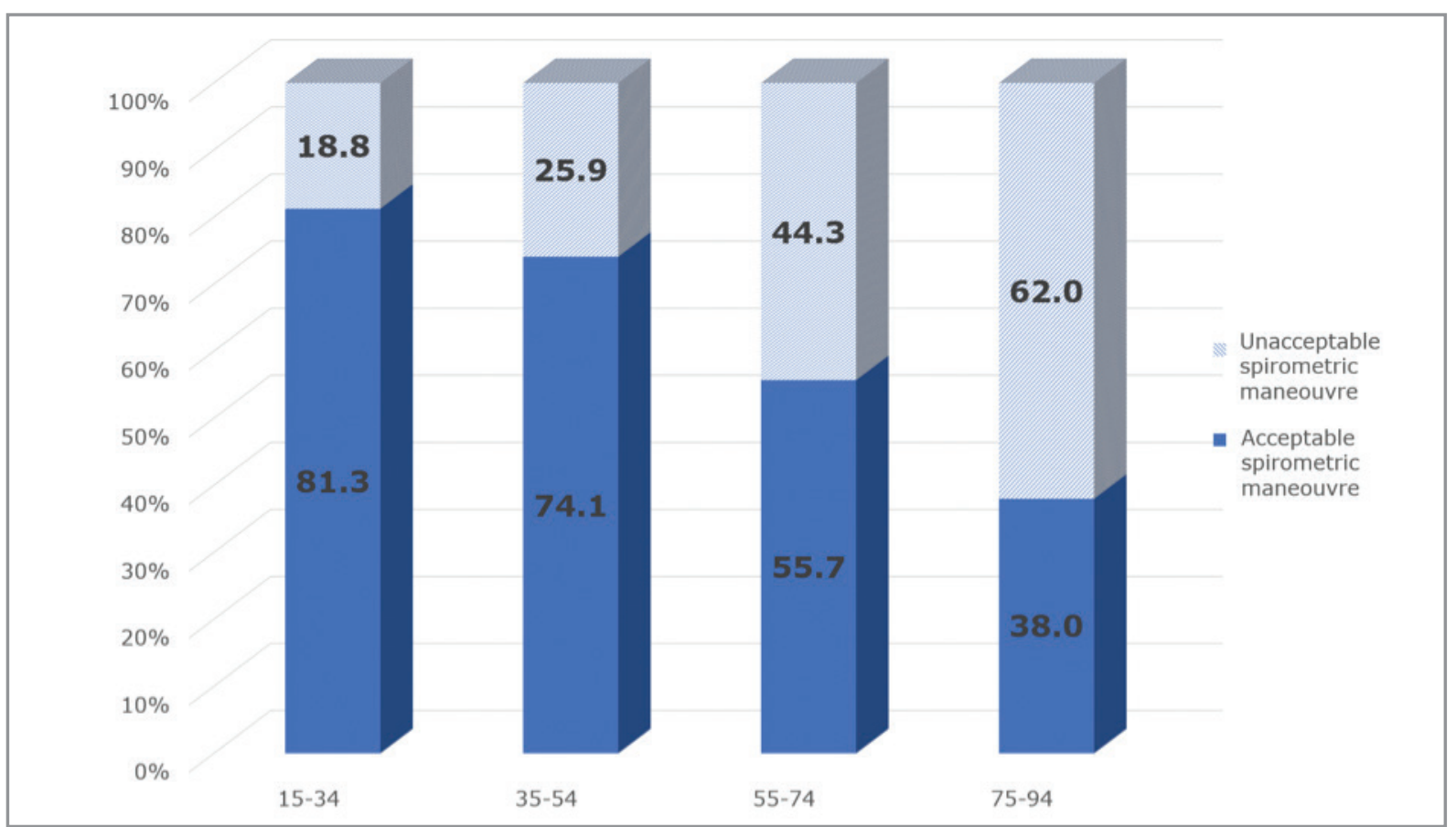

Figure 1. Ratio of conforming and non-conforming spirometric tests as per age distribution.

When conforming and non-conforming cases regarding spirometric manoeuvres were compared, it is noted that the mean age was statistically higher in non-conforming cases. There is no statistically significant difference in gender distribution of the two groups (Table 2). When the cases were grouped according to their age, it was observed that the rate of conformity of spirometric examinations decreased significantly as the age range increased $(p<0.001)$ (Figure 1).

\section{DISCUSSION}

As spirometry is mostly used in chest diseases, the conformity of this test mostly affects the practical clinic of this branch. In our country, in general, it is thought that spirometric evaluation in clinical practice do not generally conform and that this issue is a general problem. However there is no data available in means of rate of spirometric test being carried out correctly (5).

With this study it is the first time in our country that evaluation of spirometric studies has been made to see the rate of conformity with the international standards. It was seen that spirometric tests which do not conform acceptability criteria was at significant rates. The most common type of error recorded was submaximal effort. The rate of spirometric tests that did not meet the criteria was higher in elderly cases.

Krowka et al. reported, in 1987, that accurate spirometric measurements are essential for diagnosis of airway obstruction. According to their report, submaximal manoeuvres as well as manoeuvres with artefacts may lead to an underestimation of vital 
capacity and forced expiratory volume in one second. Also, rarely overestimation of forced expiratory volume in one second might result in case of submaximal effort during test, due to a decrease in dynamic compression of the airways. They have concluded that, values from spirometry manoeuvres that demonstrate submaximal effort be discarded (6).

Although international guidelines and standards are identified for quality of spirometric tests, unconformity of tests has been reported to be a clinical problem (7).

In primary care settings, the rate of spirometric tests meeting the acceptability and reproducibility criteria is low (8). Training of the staff performing spirometry improved quality of spirometric manoeuvres; with the fact that the longer and more intensive the courses, the better the results (8-10). In previous studies older age was found to be a independent factor which influences the quality of spirometric evaluations (11).

Spirometric evaluations are also essential for prevalance studies in chronic lung diseases. In Ministry of Health, Public Health Institute Chronic Diseases and Risk Factors Prevalence Study, which investigated the prevalence of chronic respiratory diseases in our country, chronic obstructive pulmonary disease prevalence was investigated in two different ways to be based on pulmonary function test results and doctors diagnosis. For the aim of this study, family physicians referred individuals with chronic obstructive pulmonary disease to a health institution to have spirometric evaluation. The test result brought to the family physician by the subjects were written in the electronic questionnaire. In the data analysis of the collected data, $\mathrm{FEV}_{1} / \mathrm{FVC} \%$ below 5 and above 120 and $\mathrm{FEV}_{1} \%$ below 5 were considered as incorrect data and excluded from the analysis. Accordingly $35.7 \%$ of the study group's initial spirometry and $22.6 \%$ of post-bronchodilator spirometry were found to be within the appropriate limits (5). However in this study, no evaluation has been made as to whether the spirometric tests performed in this study meet the international standards.

For the aim of the present study, randomly selected spirometric tests were evaluated in means of conforming or non-conforming international acceptability criteria. The prerequisities of a proper spirometric evaluation such as correct calibration of the spirom- eter and whether a minimum of three FVC manoeuvres were performed and whether repeatability is achieved were out of the scope of the study. Since the center where the study was conducted is a tertiary chest diseases hospital, it was aimed to reveal to what extent the spirometric tests directed to the physician meet the acceptability criteria, considering that other prerequisites should already be met.

According to the data of the present study, despite the fact that the study was carried out in a tertiary chest hospital, within the spirometric evaluation a significant rate does not comply with the standards. So it is clear that measures should be taken in order to yield better spirometric evaluations. Within this, measurements should be improved in carrying out efforts for standardizing spirometric measurements technically. Subjects undergoing spirometric evaluations need coaching and feedback on maneuvering. Trained technicians should administer and monitor tests to manoeuvre patients correctly to warrant clinically valid spirometric measurements. Lastly the study data also reveals that tests for senior cases should be carried out more carefully.

\section{CONFLICT of INTEREST}

The authors declare that there are no conflicts of interest.

\section{AUTHORSHIP CONTRIBUTIONS}

Concept/Design: KA, FA

Analysis/Interpretation: KA, AF, FA

Data Acquisition: AF

Writting: $K A, A F, F A$

Critical Revision: KA, FA

Final Approval: KA, AF, FA

\section{REFERENCES}

1. Townsend MC; Occupational and Environmental Lung Disorders Committee. Spirometry in the occupational health setting-2011 update. I Occup Environ Med 2011;53(5):569-84.

2. NIOSH Spirometry Quality Assurance: Common Errors and Their Impact on Test Results. DHHS (NIOSH) Publication No. 2012-116. January 2012 (https://www. cdc.gov/niosh/docs/2012-116/pdfs/2012-116.pdf; Accessed at December 22, 2019).

3. Miller MR, Hankinson J, Brusasco V, Burgos F, Casaburi R, Coates $A$, et al; ATS/ERS Task Force. Standardisation of spirometry. Eur Respir J 2005;26(2):319-38. 
4. Ulubay G, Köktürk N, Görek Dilektaşlı A, Şen E, Çiftci F, Demir T, e al. Turkish Thoracic Society national spirometry and laboratory standards. Tuberk Toraks 2017;65(2):11730.

5. T.C. Sağlık Bakanlığı Türkiye Halk Sağlığı Kurumu Kronik Hastalıklar ve Risk Faktörleri Sıklı̆̆ Çalışması. Ankara 2013. ISBN: 978-975-590-461-0, Sağlık Bakanlığı Yayın No: 909

6. Krowka MJ, Enright PL, Rodarte JR, Hyatt RE. Effect of effort on measurement of forced expiratory volume in one second. Am Rev Respir Dis 1987;136(4):829-33.

7. Derom E, van Weel C, Liistro G, Buffels J, Schermer T, Lammers $E$, et al. Primary care spirometry. Eur Respir J 2008;31(1):197-203.

8. Eaton T, Withy S, Garrett JE, Mercer J, Whitlock RM, Rea HH. Spirometry in primary care practice: the importance of quality assurance and the impact of spirometry workshops. Chest 1999;116:416-23.
9. Bellia V, Pistelli R, Catalano F, Antonelli-Incalzi R, Grassi V, Melillo G, et al. Quality control of spirometry in the elderly. The SA.R.A. study. SAlute Respiration nell'Anziano $=$ Respiratory Health in the Elderly. Am J Respir Crit Care Med 2000;161:1094-100.

10. Schermer TR, Jacobs JE, Chavannes NH, Hartman J, Folgering HT, Bottema BJ, et al. Validity of spirometric testing in a general practice population of patients with chronic obstructive pulmonary disease (COPD). Thorax 2003;58(10):861-6.

11. Enright $P$, Vollmer $W M$, Lamprecht $B$, Jensen $R$, Jithoo $A$, Tan W, et al. Quality of spirometry tests performed by 9893 adults in 14 countries: the BOLD Study. Respir Med 2011;105(10):1507-15. 